\title{
Comparative Study on the Overall Performance of Merged Public Sector Banks and Private Sector Banks using CAMEL Model
}

\author{
S. M. Riha Parvin ${ }^{1}$, Catherine Nirmala ${ }^{2}$, Niyaz $^{3}$ \\ ${ }^{1}$ Research Scholar, College of Management and Commerce, Srinivas University, Mangalore, \\ India. \\ OrcidID: 0000-0003-4030-6445; E-mail: riharafiq123@ gmail.com \\ ${ }^{2}$ Professor, P.G. Department of Business Administration, Alvas Institute of Engineering and \\ Technology, Mijar, Moodbidri, India. \\ OrcidID: 0000-0003-0088-7193; E-mail: cathnirdavid@gmail.com \\ ${ }^{3}$ Research Professor, College of Management and Commerce, Srinivas University, \\ Mangalore, India. \\ OrcidID: 0000-0003-4568-1658; E-mail: niyaz0191@gmail.com
}

Area/Section: Management.

Type of the Paper: Research Analysis.

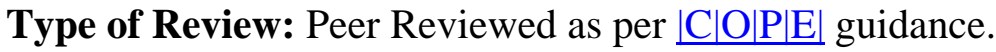

Indexed in: OpenAIRE.

DOI:

Google Scholar Citation: $\underline{\text { IJMTS }}$

\section{How to Cite this Paper:}

Riha Parvin, S. M., Catherine, Nirmala., \& Niyaz, (2021). Comparative Study on the Overall Performance of Merged Public Sector Banks and Private Sector Banks using CAMEL Model. International Journal of Management, Technology, and Social Sciences (IJMTS), 6(2), 244-255. DOI:

International Journal of Management, Technology, and Social Sciences (IJMTS)

A Refereed International Journal of Srinivas University, India.

CrossRef DOI: https://doi.org/10.47992/IJMTS.2581.6012.0168

(C) With Author.

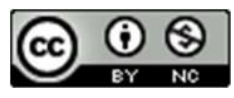

This work is licensed under a Creative Commons Attribution-Non-Commercial 4.0 International License subject to proper citation to the publication source of the work.

Disclaimer: The scholarly papers as reviewed and published by the Srinivas Publications (S.P.), India are the views and opinions of their respective authors and are not the views or opinions of the SP. The SP disclaims of any harm or loss caused due to the published content to any party. 


\title{
Comparative Study on the Overall Performance of Merged Public Sector Banks and Private Sector Banks using CAMEL Model
}

\author{
S. M. Riha Parvin ${ }^{1}$, Catherine Nirmala ${ }^{2}, \&$ Niyaz $^{3}$ \\ ${ }^{1}$ Research Scholar, College of Management and Commerce, Srinivas University, Mangalore, \\ India. \\ OrcidID: 0000-0003-4030-6445; E-mail: riharafiq123@gmail.com \\ ${ }^{2}$ Professor, P.G. Department of Business Administration, Alvas Institute of Engineering and \\ Technology, Mijar, Moodbidri, India. \\ OrcidID: 0000-0003-0088-7193; E-mail: cathnirdavid@ gmail.com \\ ${ }^{3}$ Research Professor, College of Management and Commerce, Srinivas University, \\ Mangalore, India. \\ OrcidID: 0000-0003-4568-1658; E-mail: niyaz0191@gmail.com
}

\begin{abstract}
Purpose: The main motive of this research was to assess the overall functioning of public sector banks before merger and after the merger. At the same time effective comparison is been undertaken between public and private sector banks. One of the most crucial practices of evaluating the performance of bank involves critical examination of account statements concerning annual report. Major parameters for evaluating the Banks's performance include assessment of adequate capital, quality of assets, ability of management to control the risk, earning capacity and liquid adequacy to meet the monetary obligations by the banks. Impact of merger on the bank's performance are measured and compared to judge its effectiveness.

Methodology: Quarterly published financial statements from 2019-20 to 2020-21 of selected banks are used for the analysis. Analysis is based on CAMEL model where the performance is rated on a scale of 1 to 5 on the basis of rating analysis. This study applied t-test as inferential statistics to draw a conclusion based on a comparative analysis.

Findings: The study revealed there is significant difference in the performance of selected merged public sector banks and private banks and it was found that even after the merger of public sector banks it is not able to strive against private sector banks in their overall performance.
\end{abstract}

Originality: It may be helpful to the government in making the merger an effective strategy by changing its policies and practices in consolidating the banks. Banking sectors are the major contributor to country's GDP hence the result of this study can be utilized to improve both public and private sector banks.

Utilitarian Implication: This study will be valuable and pragmatic to the various stakeholders like investors, banking sectors, government, employees, customers, management and society as a whole to maintain their stake in these banks.

Paper Type: Analytical Research

Keywords: Bank Performance, CAMEL Model, Merger, Public Sector Banks, Private Sector Bank, Effectiveness.

\section{INTRODUCTION :}

Merger of bank is an effective strategy to have a better control. In India, at present there are 12 nationalized banks after the merger of April 1, 2020. Allahabad Bank merged into Indian Bank; Andhra Bank and Corporation Bank merged into Union Bank of India; Oriental Bank of Commerce and United Bank of India merged into Punjab National Bank (PNB) and lastly Syndicate Bank merged into Canara Bank [1]. Measuring the overall performance of bank is the need of the hour, as customers' and other stakeholders' trust and confidence is dependent on the reputation of the banks. It can be analyzed by finding its overall performance. CAMEL technique is a very important tool to examine the financial 
ability of a bank and to enhance the effectiveness of a bank. In India, RBI utilizes this tool to judge the performance of banks which includes (C) Capital adequacy, (A) Assets quality, (M) Management soundness, (E) Earnings, (L) Liquidity [2]. The present research is conducted to analyze the overall performance of Private banks and merged public sector banks with special reference to four public sector banks (Punjab National Bank, Canara Bank, Indian Bank and Union Bank of India) and four private sector banks (ICICI Bank, Axis Bank, Karnataka Bank and HDFC Bank).

The consolidation of bank plans to improve the conditions of banking sector which is suffering from huge amount of bad debts and to have better governance, underwriting, monitoring, Competing and introducing technology to reduce NPAs of PSBs [3]. Now the question is whether merger actually fulfills the above requirement. The main context of the study is to find out whether these merged public sector banks are capable to strive against private banks in terms of overall performance.

\section{REVIEW OF LITERATURE :}

CAMELS rating model is a yardstick of Central Bank to measure the performance as well as to establish control over the nonperforming banks. This model is not only a controlled operation for Central Bank but it is also a very useful tool for the banks itself to assess its performance level thereby improve its efficiency [4][5]. There is a huge need of realizing the defects and inefficiency in banking operations to solve these issues and improve its financial health, which can be evaluated and controlled using CAMELS Technique [6]. In this technique the first parameter depicts the capital adequacy of the bank where the capacity of bank in order to tackle the future unexpected losses can be analyzed using various formulae like capital funds to risk weighted assets, debt-equity ratio, etc. [4]. Second component of this model is the quality of banking assets where it measures how far the non-performing asset can impact the financial health of bank [7]. A third component deal with the quality of management, measuring this ratio is complex as this is qualitative assessment. There are various formulae to calculate this ratio which includes total advances to total deposit, operating expense to assets, etc. [8]. Earning ability of banks are analyzed using the formulae Return on Asset, Return on Equity etc. which helps in analyzing the firms capacity to generate revenue or income by utilizing its assets or equities [9]. Bank's liquidity status is as important as any of the components. This measure helps the banking institutions to protect its activity from liquidity crunch and it is calculated using various formulae like liquid asset to total asset, liquid asset to total deposit, etc. [10]. The new parameter which was added to the CAMEL model is Sensitivity ratio after which it is called as CAMELS Model. This study utilizes CAMEL model for the effective evaluation of banking performance. After the brief review of the performance evaluation model the researchers attempted to review various other articles related to the main objective of our study to establish the foundation for further research and those articles include performance evaluation before and after the merger process as well as the effective comparison between two prominent sectors of Indian banking system.

Table 1: This section reviews the various literatures on merger and relative investigation of performance between public and private banks.

\begin{tabular}{|c|c|l|c|}
\hline SI. No & Area & \multicolumn{1}{|c|}{ Contribution } & Authors \\
\hline 1 & Merger & $\begin{array}{l}\text { Merger refers to consolidation of two or more } \\
\text { companies into one. }\end{array}$ & $\begin{array}{c}\text { Svetlana Santosh, } \\
\text { T., \& Dinesh, H. } \\
\text { (2016). [11] }\end{array}$ \\
\hline 2 & $\begin{array}{c}\text { Merger } \\
\text { Intention and } \\
\text { Complexities }\end{array}$ & $\begin{array}{l}\text { The merger strategy helps the banks to improve } \\
\text { customer services and operational efficiency and to } \\
\text { maintain cost effective deposits and branches. But } \\
\text { combining and merging of banks are complex task, } \\
\text { as many nationalized banks are facing affliction } \\
\text { and perilous situation. }\end{array}$ & $\begin{array}{c}\text { Kambar, P. } \\
\text { (2019). [12] }\end{array}$ \\
\hline 3 & $\begin{array}{l}\text { Pre and Post } \\
\text { Merger }\end{array}$ & $\begin{array}{l}\text { Merger of banks have highly impacted the } \\
\text { employees and shareholders. As this study made a } \\
\text { pre and post-merger comparison which showed no } \\
\text { remarkable difference between pre and post- }\end{array}$ & $\begin{array}{c}\text { Ambawade, S. H. } \\
\text { (2017). [13] }\end{array}$ \\
\hline
\end{tabular}




\begin{tabular}{|c|c|c|c|}
\hline & & $\begin{array}{l}\text { amalgamation in capital adequacy, NPA to net } \\
\text { advances ratio, return on net worth and Liquid asset } \\
\text { to total Asset ratio of all the transferee banks }\end{array}$ & \\
\hline 4 & $\begin{array}{c}\text { Financial } \\
\text { performance }\end{array}$ & $\begin{array}{l}\text { Relative analysis of pre and post-merger of both } \\
\text { private and public sector banks showed there is } \\
\text { volatility in the financial performance of Public } \\
\text { banks but private banks have stable and better } \\
\text { financial health. }\end{array}$ & $\begin{array}{c}\text { Sapna, K., \& } \\
\text { Sachin, S. (2016). } \\
\text { [14] }\end{array}$ \\
\hline 5 & $\begin{array}{l}\text { Merger of } \\
\text { Public and } \\
\text { Private banks. }\end{array}$ & $\begin{array}{l}\text { Merged private sector banks are functioning well } \\
\text { compared to merged public sector banks in the } \\
\text { analyzed financial performance of pre and post- } \\
\text { amalgamation. }\end{array}$ & $\begin{array}{l}\text { Jagadish, R., \& } \\
\text { Raiyani. (2010). } \\
\text { [15] }\end{array}$ \\
\hline 6 & $\begin{array}{l}\text { Performance } \\
\text { evaluation and } \\
\text { CAMEL }\end{array}$ & $\begin{array}{l}\text { Performance evaluation of any bank is a } \\
\text { complicated task, as it is an important tool to } \\
\text { measure, interpret, and evaluate the effectiveness } \\
\text { and efficiency of banks in attaining the prescribed } \\
\text { goal. Capital adequacy Ratios, Assets quality } \\
\text { Ratios, Management earnings Ratios, Earning } \\
\text { Ability Ratios, Liquidity Ratios of the selected } \\
\text { private and public Banks were compared and } \\
\text { overall, private banks were found immensely better } \\
\text { than public sector Banks according to the CAMEL } \\
\text { parameters }\end{array}$ & $\begin{array}{l}\text { Jalpa C., D., \& } \\
\text { B.L., S. (2016). } \\
\quad[16]\end{array}$ \\
\hline 7 & $\begin{array}{l}\text { Private sector } \\
\text { benchmark }\end{array}$ & $\begin{array}{l}\text { The public sector banks have made a remarkable } \\
\text { progress, but they still lack in reaching the } \\
\text { benchmark setup by the private sector banks as } \\
\text { NPA is well controlled by them }\end{array}$ & $\begin{array}{c}\text { Vadrale, K. S. } \\
\text { (2019). [17] }\end{array}$ \\
\hline 8 & $\begin{array}{l}\text { Position of } \\
\text { banks }\end{array}$ & $\begin{array}{l}\text { The analysis of other studies showed that Axis } \\
\text { Bank is in top Position and second Position by } \\
\text { HDFC, Third position by ICICI bank according } \\
\text { CAMEL model. As the maximum top positions are } \\
\text { dominated by Private Banking institutions it is } \\
\text { clearly Indicated that Private sector Banks have } \\
\text { strong Performance and risk management } \\
\text { Practices. }\end{array}$ & $\begin{array}{l}\text { Santoshi Kumari, } \\
\text { G., \& M S V, P. } \\
\quad \text { (2016). [18] }\end{array}$ \\
\hline 9 & $\begin{array}{l}\text { Comparison of } \\
\text { private banks }\end{array}$ & $\begin{array}{l}\text { When the CAMEL technique was used to analyze } \\
\text { the two private sector banks it showed no } \\
\text { significant difference which depicts similarity of } \\
\text { performance among the private banks. }\end{array}$ & $\begin{array}{l}\text { Srinivas, K., \& } \\
\text { Saroja, L. (2013). } \\
\text { [19] }\end{array}$ \\
\hline 10 & $\begin{array}{l}\text { Effective } \\
\text { merger }\end{array}$ & $\begin{array}{l}\text { In order to implement effective merger, } \\
\text { management strategies and policies must be } \\
\text { revised and formulated in such a way that it } \\
\text { improves the internal and external efficiency in the } \\
\text { operation of banks. Marketing strategies would } \\
\text { ensure the better performance of banks. }\end{array}$ & $\begin{array}{l}\text { Singh, S., \& Das, } \\
\text { S. (2018). [20] }\end{array}$ \\
\hline
\end{tabular}

Economic growth of country is positively related to development of financial sector. Therefore, banking sector majorly contributes to economic development of a country so mergers and acquisition of banks should be carried out systematically [14]. The successful merger can be achieved with adequate credit and depository balance along with consistent profit and strategic NPA management [13]. According to the study, among all banks HDFC is in top position in terms of performance next are ICICI and BOB [21]. Hence majority of the article highlight the performance bench marks set up by private banks and depicts the inability of public banks in meeting their standard. This study attempts to identify the remarkable difference in the performance of Public banks after the merger by comparing its performance with private banks. 


\section{RESEARCH GAP :}

Research gap found from the literature is that there is a need to find out the overall performance of public sector banks after the mergers and to conduct the effective comparison between the merged nationalized banks and Private Banks. Hence, the present study is significant and unique in its kind.

\section{OBJECTIVES OF THE STUDY :}

(1) To analyze the overall functioning of public sector banks before and after the merger.

(2) To compare the overall performance of merged public sector banks and private banks in order to assess the effectiveness of merger.

\section{HYPOTHESIS OF THE STUDY :}

$\mathbf{H}_{1}$ : Performance benchmarks setup by the private banks are better than merged nationalized banks.

\section{RESEARCH METHODOLOGY :}

The research design of this paper is based on analytical research. The main research problem signifies growing NPAs among banking sectors. This study is restricted to the four recently merged public sector banks (Union Bank of India, Canara Bank, Indian Bank and Punjab National Bank) only and their performance is compared with the four top private banks (Axis Bank, HDFC Bank, ICICI Bank and Karnataka Bank). To evaluate the overall performance of selected banks CAMEL technique is been used. For which the quarterly financial statement of selected banks is referred from 2019-20 to 202021. This study has evolved both accounting technique - ratio analysis and statistical technique $-\mathrm{t}$-test. Based on the averages of Capital adequacy ratio, Asset quality ratio, Management quality ratio, Earning quality ratio and Liquidity ratio ranks are been allotted for the selected banks. This study applied t-test as inferential statistics to draw a conclusion based on a comparative analysis. Lastly performance is rated on a scale of 1 to 5 on the basis of rating analysis.

\section{RESULTS AND DISCUSSIONS :}

From the quarterly report of selected banks all the components of CAMEL model is computed and analyzed below for the evaluation of banking performance. All the parameters are ranked on the basis of average ratio. Hence lower the mean rank better the performance of the bank and vice versa.

7.1 (C) Capital Adequacy Ratios: This ratio signifies banks' ability to maintain adequate capital in order to meet the unanticipated damages and losses. Hence high CAR contributes to better adequacy level of capital and low CAR contributes to poor adequacy level of capital [22].

Table 2: Capital Adequacy Ratios

\begin{tabular}{|l|c|c|c|c|}
\hline \multirow{2}{*}{ Banks } & \multicolumn{2}{|c|}{ CAR 2019-20 } & \multicolumn{2}{c|}{ CAR 2020-21 } \\
\cline { 2 - 5 } & Avg. & Rank & Avg. & Rank \\
\hline Canara Bank & 13.37 & 6 & 13.10 & 7 \\
\hline Union Bank of India & 13.53 & 5 & 12.35 & 8 \\
\hline Punjab National Bank & 13.32 & 7 & 13.67 & 6 \\
\hline Indian Bank & 14.32 & 4 & 14.22 & 4 \\
\hline Mean & - & 5.5 & - & 6.25 \\
\hline Axis Bank & 17.45 & 2 & 18.50 & 2 \\
\hline HDFC Bank & 17.85 & 1 & 18.93 & 1 \\
\hline ICICI Bank & 16.24 & 3 & 17.91 & 3 \\
\hline Karnataka Bank & 12.60 & 8 & 13.71 & 5 \\
\hline Mean & & 3.5 & & 2.75 \\
\hline
\end{tabular}

Source: Compiled by the Researcher

Note: Capital Adequacy Ratio= Capital Funds/ Risk Weighted Assets*100

The table 2 depicts the data of 2019-20 where the ranked average performance of private sector banks (3.5) found significantly lower than the public sector banks (5.5). Therefore, Privatized banks are stronger in maintaining CAR than nationalized banks. In the year 2020-21 average performance of private sector banks (2.75) found significantly lower than the merged public sector banks (6.25). 
Highest CAR is showed by HDFC bank (18.93\%) during research period while lowest by Union Bank (12.35\%) during the research period. Therefore, Privatized banks have done well in maintaining CAR than merged Public sector banks. This finding is supported by [23] according to which private banks hold good capital adequacy to risk weighted asset than public sector banks.

7.2 (A) Asset Quality Ratios: This ratio highlights the asset quality of banks. The quality of loan is determined on the basis of ratio level where low ratio depicts good asset quality and high ratio depicts rising non-performing asset leading to low quality of banking assets [23].

Table 3: Asset Quality Ratios

\begin{tabular}{|l|c|c|c|c|}
\hline \multirow{2}{*}{ Banks } & \multicolumn{2}{|c|}{ AQR-2019-20 } & \multicolumn{2}{c|}{ AQR-2020-21 } \\
\cline { 2 - 5 } & Avg. & Rank & Avg. & Rank \\
\hline Canara Bank & 4.945152 & 6 & 3.457763 & 6 \\
\hline Union Bank Of India & 6.673519 & 8 & 4.245881 & 7 \\
\hline Punjab National Bank & 5.214866 & 7 & 4.966483 & 8 \\
\hline Indian Bank & 3.501276 & 5 & 3.109436 & 5 \\
\hline Mean & & 6.5 & & 6.5 \\
\hline Axis Bank & 2.050879 & 3 & 1.074708 & 2 \\
\hline HDFC Bank & 0.421602 & 1 & 0.247996 & 1 \\
\hline ICICI Bank & 1.745736 & 2 & 1.105535 & 3 \\
\hline Karnataka Bank & 3.277395 & 4 & 2.533693 & 4 \\
\hline Mean & & 2.5 & & 2.5 \\
\hline
\end{tabular}

Source: Compiled by the Researcher

Note: Net NPA'S to Net Advances $=$ Net NPA / Net Advances $* 100$

The table 3 depicts the data of 2019-20 where the ranked average performance of private sector banks (2.5) found significantly lower than the public sector banks (6.5). Therefore, Privatized banks are better in maintaining AQR than Public sector banks. In the year 2020-21 average performance of private sector banks (2.5) found significantly lower than the public sector banks (6.5). This result is supported by [23] which depict those private banks are better than merged Public sector banks in maintaining AQR.

7.3 (M) Management Quality Ratios: Management quality is concerned with the productivity of management as a whole. This ratio signifies management's ability in extending more qualitative loan by utilizing its deposits. Here high ratio shows good management quality and low ratio shows poor management quality [23].

Table 4: Management Quality Ratios

\begin{tabular}{|l|c|c|c|c|}
\hline \multirow{2}{*}{ Banks } & \multicolumn{2}{|c|}{ MQR 2019-20 } & \multicolumn{2}{c|}{ MQR 2020-21 } \\
\cline { 2 - 5 } & Avg. & Rank & Avg. & Rank \\
\hline Canara Bank & 70.45615 & 6 & 65.30704 & 6 \\
\hline Union Bank Of India & 69.22334 & 7 & 65.16874 & 7 \\
\hline Punjab National Bank & 64.76086 & 8 & 61.0224 & 8 \\
\hline Indian Bank & 75.37762 & 5 & 68.09807 & 5 \\
\hline Mean & & 6.5 & & 6.5 \\
\hline Axis Bank & 90.19437 & 1 & 89.334 & 1 \\
\hline HDFC Bank & 82.10452 & 3 & 84.70475 & 2 \\
\hline ICICI Bank & 87.82512 & 2 & 78.93051 & 3 \\
\hline Karnataka Bank & 78.20735 & 4 & 72.84455 & 4 \\
\hline Mean & & 2.5 & & 2.5 \\
\hline
\end{tabular}

Source: Compiled by the Researcher

Note: Total Advances to Total Deposits Ratio $=$ Total Advances $/$ Total Deposits *100 
The table 4 depicts the data of 2019-20 where the ranked average performance of private sector banks (2.5) found significantly lower than the public sector banks (6.5). Therefore, Private sector banks have done well in maintaining MQR than Public sector banks. In the year 2020-21 average performance of private sector banks (2.5) found significantly lower than the public sector banks (6.5). This analyzed data is supported by [23]. Therefore, private banks are better in comparison with merged public sector banks in maintaining MQR.

7.4 (E) Earnings Quality Ratio: The earing capacity of a bank is essential to know their financial health. High EQR shows stable income or earning capacity of banks, whereas low EQR ponders low earning capacity of bank [22].

Table 5: Earnings Quality Ratio

\begin{tabular}{|l|c|c|c|c|}
\hline \multirow{2}{*}{ Banks } & \multicolumn{2}{|c|}{ EQR 2019-20 } & \multicolumn{2}{c|}{ EQR 2020-21 } \\
\cline { 2 - 5 } & Avg. & Rank & Avg. & Rank \\
\hline Canara Bank & -0.315 & 8 & 0.23 & 7 \\
\hline Union Bank Of India & -0.075 & 7 & 0.27 & 6 \\
\hline Punjab National Bank & 0.205 & 6 & 0.1525 & 8 \\
\hline Indian Bank & 0.2675 & 4 & 0.4925 & 4.5 \\
\hline Mean & & 6.25 & & 6.375 \\
\hline Axis Bank & 0.2175 & 5 & 0.7 & 2 \\
\hline HDFC Bank & 0.5 & 3 & 0.4925 & 4.5 \\
\hline ICICI Bank & 0.8125 & 1 & 1.415 & 1 \\
\hline Karnataka Bank & 0.535 & 2 & 0.57 & 3 \\
\hline Mean & & 2.75 & & 2.625 \\
\hline
\end{tabular}

Source: Compiled by the Researcher

Note: Return on Assets $(\mathrm{ROA})=$ Net Profit after tax $(\mathrm{PAT}) /$ Total Assets $* 100$

The table 5 depicts the data of 2019-20 where the ranked average performance of private sector banks (2.75) found significantly lower than the public sector banks (6.75). Therefore, Private sector banks have performed well in maintaining EQR than Public sector banks. In the year 2020-21 average performance of private sector banks (2.625) found significantly lower than the merged public sector banks (6.375). The result of this study is grounded by [23] therefore private banks are better than merged nationalized banks in maintaining EQR.

7.5 (L) Liquidity: Liquidity is mainly concerned with liquid assets of banks i.e., cash and balance with Reserve Bank of India, money at call and short notice and balance with other banks. This measure shows the level of liquid asset in proportion to total asset. High liquid asset depict good liquid position and low liquid asset depicts poor liquidity position of banks [18].

Table 6: Liquidity

\begin{tabular}{|l|c|c|c|c|}
\hline \multirow{2}{*}{ Banks } & \multicolumn{2}{|c|}{ LR 2019-20 } & \multicolumn{2}{c|}{ LR 2020-21 } \\
\cline { 2 - 5 } & Avg. & Rank & Avg. & Rank \\
\hline Canara Bank & 10.32309 & 2 & 12.70966 & 1 \\
\hline Union Bank of India & 8.740657 & 3 & 7.566615 & 4 \\
\hline Punjab National Bank & 11.63789 & 1 & 8.836329 & 3 \\
\hline Indian Bank & 6.202755 & 7 & 6.49665 & 6 \\
\hline Mean & & 3.25 & & 3.5 \\
\hline Axis Bank & 6.916595 & 5 & 6.47441 & 7 \\
\hline HDFC BANK & 6.299022 & 6 & 6.755082 & 5 \\
\hline ICICI BANK & 7.937467 & 4 & 11.11661 & 2 \\
\hline Karnataka Bank & 4.390834 & 8 & 4.304384 & 8 \\
\hline Mean & & 5.75 & & 5.5 \\
\hline
\end{tabular}

Source: Compiled by the Researcher

Note: Liquidity Asset to Total Asset = Liquid Assets/ Total Assets* 100 
The table 6 depicts the data of 2019-20 where the ranked average performance of public sector banks (3.25) found significantly lower than the private sector banks (5.75). Therefore, public sector banks have maintained better LR than private sector banks. In the year 2020-21 average performance of public sector banks (3.5) found significantly lower than the private sector banks (5.5). The result of this study is also grounded by [23] therefore merged public sector banks have outperformed private banks in maintaining LR.

7.6 Overall CAMEL rank test: On the basis of ranked ratio of CAMEL parameters, overall analysis is been done to draw an inference.

$\mathrm{H} 0=0$ Performance benchmarks setup by the private banks are equal to merged nationalized banks.

$\mathrm{H} 1>0$ Performance benchmarks setup by the private banks are better than merged nationalized banks.

Table 7: T-Tests for Overall CAMEL Rank 2019-20 and 2020-21

\begin{tabular}{|l|c|c|c|c|}
\hline \multirow{2}{*}{\multicolumn{1}{|c|}{ Variable }} & \multicolumn{2}{c|}{ 2019-20 } & \multicolumn{2}{c|}{ 2020-21 } \\
\cline { 2 - 5 } & Public Sector & Private Sector & $\begin{array}{c}\text { Public } \\
\text { Sector }\end{array}$ & Private Sector \\
\hline Mean value & 6.25 & 2.75 & 6.5 & 2.5 \\
\hline No. of observation (n) & 4 & 4 & 4 & 4 \\
\hline Degrees of freedom & \multicolumn{2}{|c|}{6} & \multicolumn{2}{c|}{4.38178046} \\
\hline t Statistics & \multicolumn{2}{|c|}{2.898275349} & \multicolumn{2}{c|}{0.01} \\
\hline "p" value (two-tailed) & \multicolumn{2}{|c|}{0.02} & \multicolumn{2}{c|}{2.447} \\
\hline t Critical (two-tailed) (5\%) & \multicolumn{2}{|c|}{2.447} & \\
\hline
\end{tabular}

Source: Compiled by the Researcher

Table 7 shows that in the year 2019-20 according to the t-test analysis null Hypothesis is been rejected as $t$ stat value is 2.89 which is more than $t$ critical value 2.447 , it means that there is significant difference between the Overall CAMEL rank of Public and private sector banks. It shows that the rank of average performance in maintaining the Overall CAMEL rank of private sector banks (2.75) found significantly lower than the public sector banks (6.25). Therefore, Performance benchmarks setup by the private banks are better than nationalized banks. Similarly in the year 2020-21, Null Hypothesis is rejected as $\mathrm{t}$ stat value is 4.38 which is more than $\mathrm{t}$ critical value 2.447 , consequently significant difference is found between the Overall CAMEL rank of merged Public sector banks and private sector banks. It shows that the rank of average performance in maintaining the Overall CAMEL parameters of private sector banks (2.5) found significantly lower than the merged public sector banks (6.5). This finding is supported by [23]. Hence, Performance benchmarks setup by the private banks are better than merged nationalized banks.

Table 8: Ratings of Selected Public \& Private Sector Banks based on Overall Average rank

\begin{tabular}{|c|c|c|c|c|}
\hline $\begin{array}{c}\text { Rating } \\
\text { (Overall) }\end{array}$ & $\begin{array}{c}\text { Camel } \\
\text { Criteria }\end{array}$ & $\begin{array}{c}\text { Mean } \mathbf{4 . 5} \text { And } \\
\text { Standard } \\
\text { Deviation=2.45 }\end{array}$ & $\begin{array}{c}\text { Banks Under } \\
\text { Study } \\
\mathbf{2 0 1 9 - 2 0}\end{array}$ & $\begin{array}{c}\text { Banks Under } \\
\text { Study 2020-21 }\end{array}$ \\
\hline $\begin{array}{c}\text { '1' Or A+ } \\
\text { (Excellent) }\end{array}$ & $\begin{array}{c}\text { Up to (Mean- } \\
0.67 \text { SD) }\end{array}$ & 2.86 & $\begin{array}{c}\text { ICICI Bank, } \\
\text { HDFC Bank }\end{array}$ & $\begin{array}{c}\text { ICICI Bank, } \\
\text { HDFC Bank, } \\
\text { Axis Bank }\end{array}$ \\
\hline '2' Or A (Good) & $\begin{array}{c}\text { From (Mean- } \\
0.67 \text { SD) }\end{array}$ & $2.86-4.5$ & Axis Bank & - \\
\hline '3' Or B (Fair) & $\begin{array}{c}\text { Up to (Mean+ } \\
0.67 \text { SD) }\end{array}$ & $4.51-6.14$ & $\begin{array}{c}\text { Canara Bank, } \\
\text { Indian Bank, } \\
\text { Karnataka Bank, } \\
\text { Union Bank of } \\
\text { India, Punjab } \\
\text { National Bank }\end{array}$ & $\begin{array}{c}\text { Karnataka Bank, } \\
\text { Indian Bank, } \\
\text { Canara Bank }\end{array}$ \\
\hline
\end{tabular}




\begin{tabular}{|c|c|c|c|c|}
\hline \hline ‘4' Or C (Poor) & $\begin{array}{c}\text { Above (Mean } \\
+0.67 \text { SD) }\end{array}$ & Above 6.14 & - & $\begin{array}{c}\text { Punjab National } \\
\text { Bank, Union } \\
\text { Bank of India }\end{array}$ \\
\hline $\begin{array}{c}\text { ‘5' Or D (V. } \\
\text { Poor) }\end{array}$ & $\begin{array}{c}\text { Above 1.5 of } \\
\text { Mean }\end{array}$ & Above 6.75 & - & - \\
\hline
\end{tabular}

Source: Compiled by the Researcher

Table 8 shows that before the merger of public sector banks, ICICI bank \& HDFC bank has been rated on excellent position which lies in the category of (' 1 ' OR A+'). Axis Bank have been rated on good position which lies in the category of ('2' OR A). Indian Bank, Karnataka Bank, Canara Bank, Union Bank of India \& Punjab National Bank have been rated on Fair position which lies in the category of ('3' or B).

In the year 2020-21 after the merger, ICICI bank, HDFC bank \& Axis Bank has been rated on excellent position which lies in the category of (' 1 ' OR A+'). Indian Bank, Karnataka Bank \& Canara Bank have been rated on Fair position which lies in the category of Rating ' 3 ' or B. Union Bank of India \& Punjab National Bank have been rated on Poor position which lies in the category of Rating '4' OR C. the result of rating analysis supports the others findings [23][18][21].

This paper mainly studied the effectiveness of merger on banking performance and found that merger strategies of public sector banks have not shown any major difference in their overall functioning. Therefore, Performance benchmarks setup by the private banks are better than merged nationalized banks.

\section{SUGGESTION :}

CAMEL model showed, non-performing assets are the major concerns of public sector banks and also it lacks in other parameter except liquidity and maintaining high liquidity is the major concern for private banks therefore they must focus on improving the asset quality and maintaining high liquidity position. Management's efficiency also has a huge impact on the banking performance so component of accountability should be strictly followed by each bank and it must be reflected through its service quality [24]. At the same time use of technology in banking will help the management in order to improve their efficiency and to encourage more and more customers as future of bank will be customerfriendly institution with digitalization in order to accomplish continual business position [25]. Hence, technology can also contribute to the improvement of overall performance of banks.

\section{CONCLUSION :}

After the banking reforms in India, major improvements are witnessed. This improvement can be critically evaluated using CAMELS model where the comparison between public and private banks have shown the high financial ability of the later bank due to its efficient management, earning and profitability [26-28]. At the same time our study has also found that there is significant difference in the performance of selected merged public sector banks and private banks and it was found that even after the merger of public sector banks it is not able to strive against private sector banks in their overall performance. Overall functioning of public banks has not shown any progress even after the merger as the rating analysis has revealed the downward rating of selected merged banks. But private banks have shown constant progress in its overall functioning as per the rating analysis. There are many related previous works which showed high financial standard set by private banks as compared to public banks but this study found the need to identify the major changes in public banks after the merger by comparing it with private standards but found no remarkable improvement in its progress. As banking sector contributes to major part of the country's GDP it is essential to bring innovative strategies, constant growth and survival in a global market. Hence there is a need to improve banking efficiency and take effective measures to tackle any banking related issues. At the same time involvement of weaker section of the society in accessing finance provided by financial institution also helps the economic development of a country [29]. Hence, along with adopting various strategies like merger it is essential to encourage all the section of society to keep their stake in the banking institutions. Improvement in its overall performance plays a vital role in encouraging the customers to invest their interest in banks. 
10. UTILITARIAN IMPLICATION :

This study will be valuable to the investors in order to make their investment decision. At the same time this study is pragmatic to banking sectors, government, employees, customers, management and society as a whole to maintain their stake in these selected banks.

\section{SCOPE FOR FURTHER RESEARCH :}

Further research can be undertaken at a different time period as the effectiveness of merger can be experienced in the future years. The study period for CAMEL's model is only 2 years i.e., 2019-20 to 2020-21, hence more number of years can be evaluated to see the trend series of its performance. 8 banks are selected for the study representing the whole public and private sector banks, this is a limitation as selection of few banks may not give appropriate representation of the whole banking sector therefore further research can be initiated by evaluating more banks from each sector.

\section{REFERENCES:}

[1] Mandray, J. S., \& Kamal, R. (2020). Mergers of Public sector Undertaking Banks in India. International Journal of Creative Research Thoughts (IJCRT), 8(7), 4169-4172. Google Scholar $\chi^{\top}$

[2] Elizabeth M. Samuel, (2018). Comparative Performance Evaluation of Selected Commercial Banks in India using CAMELS Rating Model, International Journal of Global Sustainability, Macrothink Institute, 2(1), 24-38.

Google Scholar ${ }^{7}$

[3] Kavitha, S. (2020). A study on the consolidation and merger of PSB's in India: Issues and Challenges-with special reference to PNB, OBC, and United Bank. The International journal of analytical and experimental modal analysis, 12(1), 2300-2307.

Google Scholar $x^{7}$

[4] Aspal, P. K., \& Dhawan, S. (2016). Camels rating model for evaluating financial performance of banking sector: A theoretical perspective. International Journal of System Modeling and Simulation, 1(3), 10-15.

Google Scholar $X^{\top}$

[5] Bodla, BS and Verma, R, (2006). Evaluating performance of banks through CAMEL model: A Case Study of SBI and ICICI. The ICFAI Journal of Bank Management, 5(3), 49-63.

Google Scholar $X^{\top}$

[6] Milligan, J. (2002). Guess who’s rating your bank. ABA Banking Journal, 94(10), 68-76.

Google Scholar $\chi^{\top}$

[7] Samuel, E. M. (2018). Comparative performance evaluation of selected commercial banks in India using CAMELS rating model. International Journal of Global Sustainability, 2(1), 24-38. Google Scholar X

[8] Rostami, M. (2015). Determination of Camels model on bank's performance. International journal of multidisciplinary research and development, 2(10), 652-664.

Google Scholar X

[9] Roman A, Şargu A. C. (2013). Analysing the financial soundness of the commercial banks in Romania: an approach based on the camel's framework. Procedia economics and finance, 6(1), 703-712.

Google Scholar 77

[10] Dincer H, Gencer G, Orhan N, Sahinbas K. (2011). A performance evaluation of the Turkish banking sector after the global crisis via CAMELS ratios. Procedia Social and Behavioral Sciences, 24(1), 1530-1545.

Google Scholar $X^{\top}$

[11] Tatuskar, S. S. (2016). Pre merger versus post merger performance evaluation of public sector banks vis a vis privte sector banks in India that have merged during the period 19931994 to 2004 2005. http://hdl.handle.net/10603/91876. 
Google Scholar $\chi^{7}$

[12] Kambar, P. S. (2019). A study on the consolidation and merger of public sector banks (PSB) in India: Issues and challenges. International Journal of Social Science and Economic Research, 4(6), 4326-4334.

Google Scholar 7

[13] Ambawade, S. H. (2017). An Impact of Merger and Acquisition on Stakeholders of Merged Banks in Sangli District. Shodhganga. http://hdl.handle.net/10603/285351.

Google Scholar $\chi^{7}$

[14] Kasliwal, S. (2016). A comparative analysis of effectiveness of mergers in private and public sector banks in India. http://hdl.handle.net/10603/235197.

Google Scholar $x^{\top}$

[15] Raiyani, J. R. (2010). Effect of mergers on efficiency and productivity of Indian banks: A CAMELS analysis. Asian Journal of Management Research, 1(1), 772-794.

Google Scholar $\nearrow^{\nearrow}$

[16] Dhaduk, J. C. (2016). A comparative study on performance evaluation of private sector bank and public sector bank in India with reference to camel model. http://hdl.handle.net/10603/117587. Google Scholar $\not$ '

[17] Vadrale, K. S. (2019). Financial Performance of Selected Public and Private Sector Banks in the Light of CAMEL Model. Wealth: International Journal of Money, Banking \& Finance, 8(1), 4958 .

Google Scholar $\not$ '

[18] Gondesi, S. K. (2016). Evaluating financial performance of select public and private sector banks using camels and eagles models. http://hdl.handle.net/10603/186037.

Google Scholar $\chi^{7}$

[19] Srinivas, K., \& Saroja, L. (2013). Comprative Financial performance of HDFC and ICICI Bank. International referred Multidesciplinary Journal of Contemrory Research. Scholars WorldInternational Refereed Multidisciplinary Journal of Contemporary Research, 1(2), 107- 126 Google Scholar X

[20] Singh, S., \& Das, S. (2018). Impact of Post-Merger and Acquisition activities on the Financial Performance of Banks: a study of Indian Private and Public sector Banks. Revista ESPACIOS, 39(26), $772-794$.

Google Scholar ${ }^{7}$

[21] Sukhla. (2015). Analysing financial strength of public and private sector Banks: A CAMEL approach. Pacific Business Review International, 7(8), 44-50.

Google Scholar $\chi^{\top}$

[22] Gadhia, N. M. (2015) The study of financial performance of selected public and private sector banks in India with reference to Camel Model. http://hdl.handle.net/10603/70693.

Google Scholar $\chi^{\top}$

[23] Bhiryani, H. (2017). Performance analysis through camel rating A Comparative Study of Selected Public and Private Sector Banks In India. http://hdl.handle.net/10603/213385.

Google Scholar ${ }^{\top}$

[24] Aithal, P. S., Kumar, Prasanna., \& Mike Dillon. (2018). How to Improve the Employee Productivity of Banking System in India - a Theory of Accountability Based Analysis. International Journal of Management, Technology, and Social Sciences (IJMTS), 3(2), 87- 99. Google Scholar $\chi^{7}$

[25] Pradeep M. D. \& Nornha Sonia D. N. (2018). Study on the Changing landscape of financial in Indian Banking System- Opportunities and Challenges. International Journal of Management, Technology, and Social Sciences (IJMTS), 3(1), 1-10.

Google Scholar $\not$ ' 
[26] Dash, M., \& Das, A. (2013). Performance Appraisal of Indian Banks Using CAMELS Rating. IUP Journal of Bank Management, 12(2), 31-42. Google Scholar $\chi^{\top}$

[27] Haralayya, D., \& Aithal, P. S. (2021). Study on Model and Camel Analysis of Banking. Iconic Research and Engineering Journals (IRE), 4(11), 244-259.

Google Scholar $x^{7}$

[28] Haralayya, D., \& Aithal, P. S. (2021). Analysis of Bank Performance Using Camel Approach. Journal of Emerging Technologies and Innovative Research (JETIR), 8(5), 305-314. Google Scholar ${ }^{\top}$

[29] Niyaz, \& Abbokar Siddiq, (2021). Awareness and Utilization on Cooperative Banking Services and Schemes in Rural Area. International Journal of Management, Technology, and Social Sciences (IJMTS), 6(2), 108-120. DOI: https://doi.org/10.5281/zenodo.5519111.

Google Scholar ${ }^{7}$ 